University of Nebraska - Lincoln

DigitalCommons@University of Nebraska - Lincoln

$10-2000$

\title{
Intensification of the Northeast Pacific Oxygen Minimum Zone During the Bolling-Allerod Warm Period
}

\author{
Yan Zheng \\ Lamont-Doherty Earth Observatory, Columbia University, Palisades, New York \\ Alexander van Green \\ Lamont-Doherty Earth Observatory, Columbia University, Palisades, New York \\ Robert F. Anderson \\ Lamont-Doherty Earth Observatory, Columbia University, Palisades, New York \\ James V. Gardner \\ U.S. Geological Survey \\ Walter E. Dean \\ U.S. Geological Survey, Denver, CO, dean@usgs.gov
}

Follow this and additional works at: https://digitalcommons.unl.edu/usgsstaffpub

Part of the Earth Sciences Commons

Zheng, Yan; van Green, Alexander; Anderson, Robert F.; Gardner, James V.; and Dean, Walter E., "Intensification of the Northeast Pacific Oxygen Minimum Zone During the Bolling-Allerod Warm Period" (2000). USGS Staff -- Published Research. 324.

https://digitalcommons.unl.edu/usgsstaffpub/324

This Article is brought to you for free and open access by the US Geological Survey at DigitalCommons@University of Nebraska - Lincoln. It has been accepted for inclusion in USGS Staff -- Published Research by an authorized administrator of DigitalCommons@University of Nebraska - Lincoln. 


\title{
Intensification of the northeast Pacific oxygen minimum zone during the Bölling-Alleröd warm period
}

\author{
Yan Zheng ${ }^{1}$, Alexander van Geen, and Robert F. Anderson \\ Lamont-Doherty Earth Observatory, Columbia University, Palisades, New York
}

James V. Gardner

U. S. Geological Survey, Menlo Park, California

Walter E. Dean

U. S. Geological Survey, Denver

\begin{abstract}
Although climate records from several locations around the world show nearly synchronous and abrupt changes, the nature of the inferred teleconnection is still poorly understood. On the basis of preserved laminations and molybdenum enrichments in open margin sediments we demonstrate that the oxygen content of northeast Pacific waters at $800 \mathrm{~m}$ depth during the Bölling-Alleröd warm period (15-13 kyr) was greatly reduced. Existing oxygen isotopic records of benthic and planktonic foraminifera suggest that this was probably due to suppressed ventilation at higher latitudes of the North Pacific. Comparison with ventilation records for the North Atlantic indicates an antiphased pattern of convection relative to the North Pacific over the past $22 \mathrm{kyr}$, perhaps due to variations in water vapor transport across Central America.
\end{abstract}

\section{Introduction}

For many regions of the globe it is now clear that the transition to modern climate following the Last Glacial Maximum (LGM) was punctuated by a number of rapid and substantial climate oscillations [Fairbanks, 1990; Alley et al., 1993]. The Bölling-Alleröd (BA) period of early warming (between 14.7 and $12.9 \mathrm{kyr} ; \sim 12.5-11.1 \mathrm{kyr}{ }^{14} \mathrm{C}$ years) and a temporary return to coolness during the Younger Dryas (YD) (between 12.9 and $11.6 \mathrm{kyr} ; \sim 11.1-10.1 \mathrm{kyr}{ }^{14} \mathrm{C}$ years), as dated in Greenland ice cores [Alley et al., 1993], appear to be linked to climate-related changes observed in many marine and continental records [Fairbanks, 1990; Peteet and Mann, 1994; Kallel et al., 1988]. Well-dated cores show that the BA and the YD correlate with changes in the oxygen content of bottom water in the Gulf of California [Keigwin, 1987] and the Santa Barbara basin [Kennett and Ingram, 1995], both semienclosed basins in the northeast Pacific, although the exact mechanism linking these rapid transitions on a global scale remains enigmatic. We contribute to this question by showing that low oxygenation of the Gulf of California and Santa Barbara basin during the BA was caused by an abrupt reduction in the oxygen content of open northeast Pacific water at $800 \mathrm{~m}$ depth. We further show that the reduction in

\footnotetext{
'Now at Queens College, City University of New York, Flushing, New York.

Copyright 2000 by the American Geophysical Union.
}

Paper number 1999PA000473.

0883-8305/00/1999PA000473\$12.00 ventilation was associated with increased stratification of $\mathrm{tl}$ upper water column at high latitudes of the North Pacif Ocean.

The oxygenminimum zone (OMZ), typically located in $\mathrm{tl}$ 500-800 m depth range, is a characteristic feature of much the global ocean, although its intensity varies widely from ol location to another. The shape and intensity of the OM reflects a balance between oxygen consumption by decayir plankton matter as it sinks from the surface and mixes wi oxygenated subsurface water produced at high latitudes 1 cooling [Wyrtki, 1962]. The OMZ of the North Pacif: centered approximately at the $\sigma_{\theta}=27.2$ density surface, most pronounced off Mexico $(<5 \mu M)$ and gradually weake to the north $(\sim 15 \mu M$ off California) and to the west $(\sim 60 \mu$ off Japan) (Figure 1). This pattern is, in part, a function distance from the Sea of Okhotsk and the Gulf of Alas. where well-oxygenated North Pacific Intermediate Wal (NPIW, $26.7<\sigma_{\theta}<26.9$ ) is formed [Talley, 199: Hydrographic time series data indicate that the intensity of $t$ OMZ off California is delicatcly balanced today with respr to variations in the relative contributions of low-oxygen wa from the south and high-oxygen water from the north [Ly. and Simpson, 1987; Van Scoy and Druffel, 1993]. Tr suggests that the California margin at the depth of the ON should be a sensitive location to reconstruct past changes the processes that regulate the intensity of the OMZ.

\section{OMZ Fluctuations in the Northeast Pacific}

In this study we use the preservation of fine laminatic and the concentrations of $\mathrm{Mo}$ and $\mathrm{Cd}$ in the sediment reconstruct past changes in the intensity of the $\mathrm{OMZ}$ California since the LGM. Along most continental margin: 


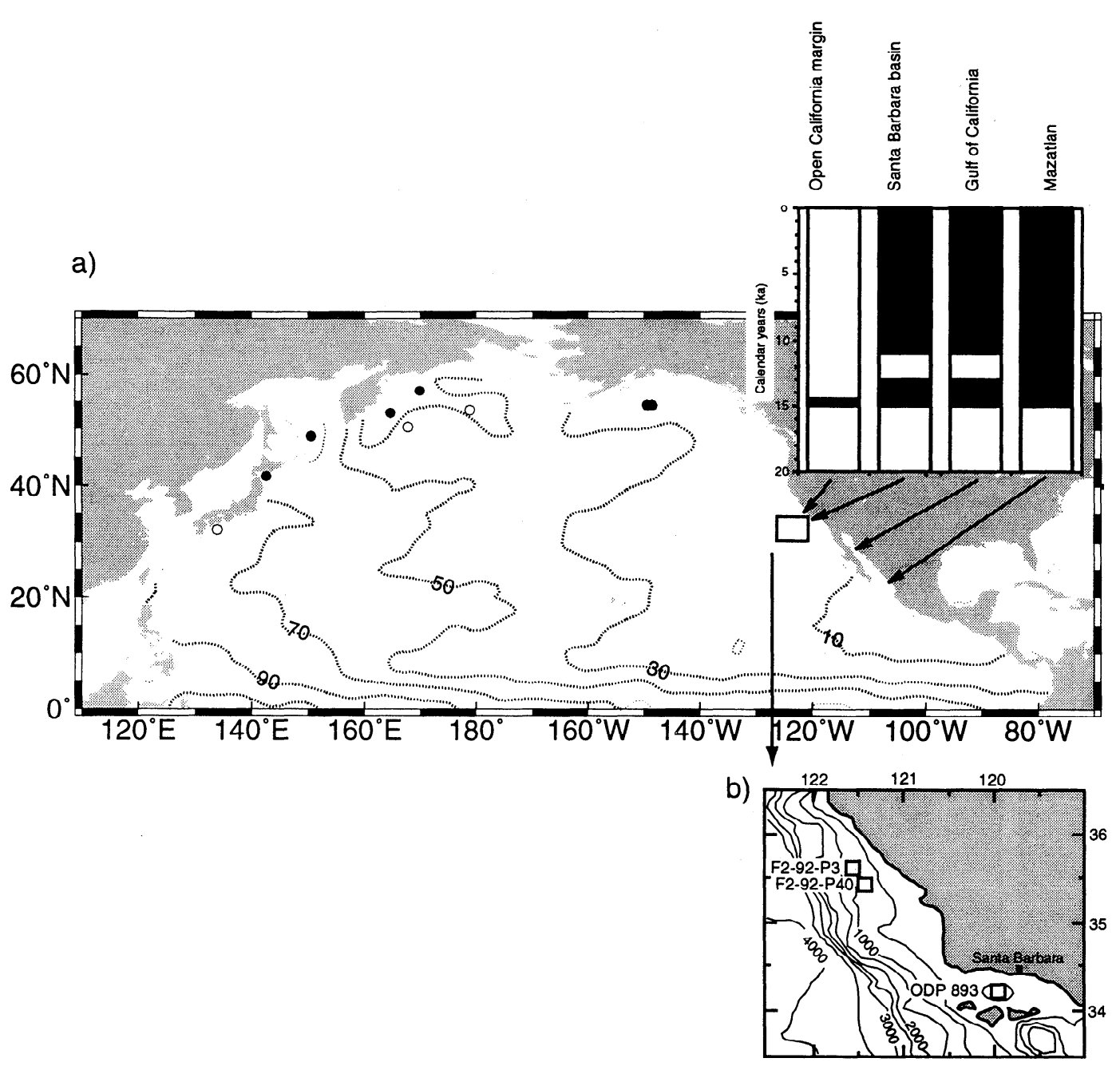

Figure 1. a) Contour map of oxygen concentrations $(\mu M)$ [Levitus and Boyer, 1994] on the $\sigma_{\theta}=27.2$ isopycnal surface. This density surface is a good approximation for the location of the OMZ across the North Pacific and increases in depth from 800 to $1000 \mathrm{~m}$ from east to west. Large open rectangle indicates enlarged study area on the California margin (Figure 1b). Locations of cores with excess shift in the $\delta^{18} \mathrm{O}$ of planktonic foraminifera relative to benthic foraminifera during the Bölling-Alleröd (BA) are indicated by solid circles (CH84-14, RAMA 44PC, core 2594, V34-90, PAR87A-01, PAR87A-02, and PAR87A-10) [Kallel et al., 1988; Zahn et al., 1991; Keigwin et al., 1992; Gorbarenko, 1996]. Locations of cores without records of benthic foraminifera but showing a large negative shift in planktonic $\delta^{18} \mathrm{O}$ at the onset of the BA are indicated by small open circles [Gorbarenko, 1996; Ohkouchi et al., 1994]. Inset of bar graphs shows alternation between laminated (black) and bioturbated sediments (white) over the past $20 \mathrm{kyr}$ at four locations in the northeast Pacific margin: the open California margin [Gardner et al., 1997], the Santa Barbara Basin [Behl and Kennett, 1996], the Gulf of California [Keigwin and Jones, 1990], and the Mexican margin off Mazatlan [Ganeshram, 1996]. Laminated and Mo-enriched surface sediments have been reported at the Mexican margin off Mazatlan as well [Nameroff, 1996] . b) Enlarged study area at the California margin where locations of cores F2-92-P3 and F2-92-P40 are indicated (open rectangle, Figure 1a). Location of Ocean Drilling Program Site 893[Kennett and Ingram, 1995] in the Santa Barbara basin is also shown.

seasonal cycle modulates the composition of particulate matter reaching the ocean floor. This signature is usually erased by burrowing activities of the benthic macrofauna. Exceptions are anoxic basins such as the Black Sea and the Cariaco Trench as well as areas where bottom water contains $<5 \mu M$ oxygen, such as the OMZ off Mexico and the Santa Barbara basin, where bioturbating organisms cannot survive. The preservation of laminations is therefore a clear indication of bottom water oxygen levels $<5 \mu M$. Sedimentary concentrations of Mo and $\mathrm{Cd}$ are also sensitive to bottom water oxygen concentrations. Both elements are enriched in marine sediments that accumulate under low-oxygen conditions because of precipitation triggered by a combination of elevated iron and sulfide concentrations in pore waters [Francois, 1988; Shaw et al., 1990; Crusius et al., 1996; Helz et al., 1996; Zheng et al., 2000]. In the case of Mo these authigenic enrichments have not been detected in sediment under bottom water oxygen levels $>10 \mu M$ (Figure 2). This compilation excludes more oxic conditions where Mo can accumulate in sediments above crustal levels in conjunction with Mn oxides [Shaw et al., 1990; Shimmield and Price, 1986]. In contrast to Mo, there is no well-defined threshold 


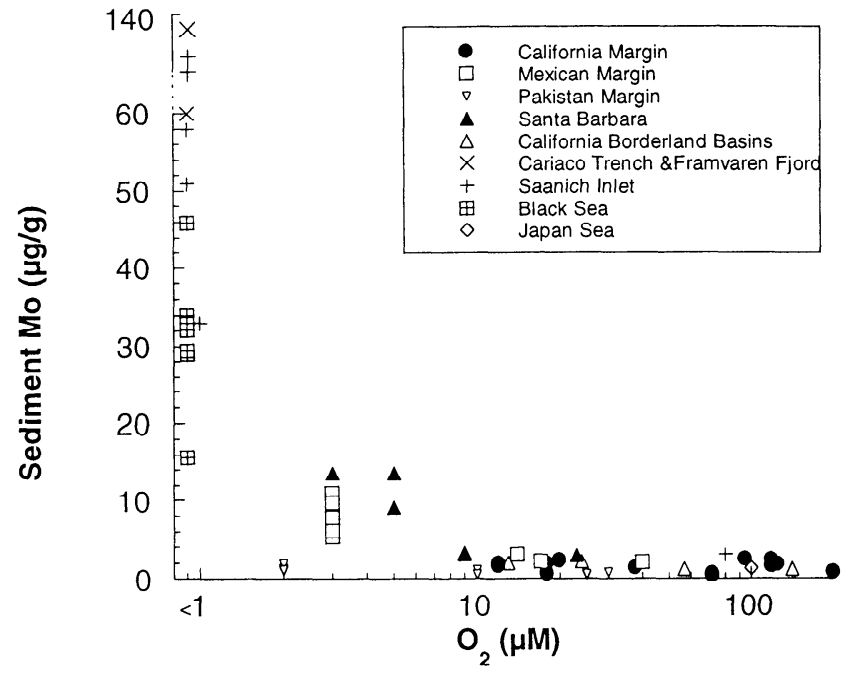

Figure 2. Relation between Mo concentration in modern sediment and bottom water oxygen concentration (California Margin [Zheng, 1999], Mexican Margin [Nameroff, 1996], Pakistan Margin [Crusius et al., 1996], and near shore ocean basins (Saanich Inlet [Francois, 1988; Crusius et al.,1996], Black Sea [Crusius et al., 1996], Japan Sea [Crusius et al., 1996], Cariaco Trench [Emerson and Huested, 1991], Framvaren Fjord [Emerson and Huested, 1991], Santa Barbara basin [Zheng, 1999] and other California Borderland Basins (Patten Escarpment, San Clemente, Santa Cruz and San Nicholas Zheng [1999])). Compilation excludes sediments in which Mo enrichments are believed to be associated with $\mathrm{Mn}$ oxyhydroxides [Shaw et al., 1990; Shimmield and Price, 1986]. Outlier from Pakistan margin suggests that in addition to low oxygen, a minimum level of organic matter is required to trigger authigenic Mo formation.

oxygen level for authigenic $\mathrm{Cd}$ formation because the rain rate of plankton matter reaching the sediment is an important factor in addition to bottom water conditions [van Geen et al., 1995].

Both fine-scale laminations and Mo enrichments are preserved in two piston cores from the continental margin off central California (F2-92-P3 at $35^{\circ} 27.4^{\prime} \mathrm{N}, 121^{\mathrm{O}} 36.3^{\prime} \mathrm{W}$; and $\mathrm{F} 2-92-\mathrm{P} 40$ at $35^{\circ} 25.09^{\prime} \mathrm{N}, 121^{\circ} 24.95^{\prime} \mathrm{W} ; 803$ and $760 \mathrm{~m}$ water depths, respectively; Figure. 1). Radiocarbon-dated planktonic and benthic foraminifera indicate that sedimentation rates in cores P3 and P40 averaged 14 and 25 $\mathrm{cm} / \mathrm{kyr}$ (Table 1), respectively, over the past $15 \mathrm{kyr}$ [Gardner et al., 1997]. The finely laminated sections preserved between 214 and $204 \mathrm{~cm}$ in core P3 and between 372 and $353 \mathrm{~cm}$ in core P40 correspond to calendar ages of 14.7-14.4 kyr and 15.0-14.6 kyr, respectively (Figures. 3a and 3b). These intervals are indistinguishable within the accuracy of the age models. Mo concentrations (Table 2) increase in both cores above a detrital background level of $-2 \mu \mathrm{g} / \mathrm{g}$ [Taylor and McLennan, 1985] in intervals deposited between 15 and 13 kyr (217-172 cm in core P3, 363-274 cm in core P40, Figures. $3 a$ and $3 b$ ). Because threshold oxygen levels for preservation of laminations appear to be lower than that for the precipitation of authigenic Mo [Zheng, 1999], we attribute these features to a rapid intensification of the OMZ off California to $<5 \mu M$ oxygen at the onset of the BA, when Mo was precipitated in laminated sediments, followed by a slight increase to $>5$ but $<10 \mu M$ through the duration of the $\mathrm{BA}$, when precipitation of Mo continued but sediments were bioturbated. This suggests a northward expansion of the intense OMZ, characteristic of the Mexican margin today, by at least $10^{\circ}$ latitude $(1000 \mathrm{~km})$ during the BA (Figure 1). The climax of poor ventilation that occurred during the early BA is consistent with the fluctuation of the oxygen minimum zone intensity based on benthic foraminifera assemblages at ODF site 1017 [Cannariato and Kennett, 1999].

Late glacial sediments in the Santa Barbara basin, the Gul: of California, and the margins of California and Mexico are bioturbated [Kennett and Ingram, 1995; Keigwin and Jones 1990; Ganeshram, 1996; Cannariato and Kennett, 1999] indicating that $\mathrm{OMZ}$ waters throughout the region containec sufficient levels of oxygen to sustain populations of benthic macrofauna (Figure 1 inset). Within the uncertaintics of the respective age models associated with these four records, thr onset of preservation of laminations was synchronous at al sites and coincident with the onset of the BA, indicating ar abrupt region-wide intensification of the $\mathrm{OMZ}$ associated witl a warming climate. Upon return to colder conditions during the YD the OMZ became better ventilated, as indicated by thi presence of bioturbated sediments at all sites except th Mexican margin (Figure 1 inset). Intensification of the $\mathrm{OM}^{r}$ coincided again with warming in the Holocene, as suggester by laminated sediments in the Santa Barbara basin and th Gulf of California (Figure 1 insel and Figure 3c). However, a no time during the Holocene did the $\mathrm{OMZ}$ off California reacl the intensity that existed during the BA for a duratiol sufficiently long to preserve laminated sediments or $\mathrm{M}_{\text {}}$ enrichments (Figure 1 inset and Figure 3c). Thi interpretation is supported by the variations in the degree $\mathrm{C}$ preservation of laminations in Santa Barbara Basin (Figure 36 Behl and Kennett, 1996). Preserved laminations and M enrichments reported for other California margin cores sugges that the OMZ may have been as intense as during the BA o several occasions before the LGM [Dean et al., 1997].

\section{Causes for Intensification of the OMZ During the BA}

What caused the intensification of the OMZ over a larg area of the northeast Pacific during the BA? One possibility $i$ that upwelling-favorable equatorward winds intensifier enhanced productivity, and intensified the OMZ owing 1 increased oxygen demand associated with regeneration of th products of enhanced productivity. A general circulatic model driven by orbital changes in insolation and melting the Laurentide ice sheet predicts an increase in equatorwar winds along the North American coast during deglaciatic [Cooperative Holocene Mapping Project (COHMAl members, 1988]. However, these changes, qualitative confirmed by productivity proxies measured in cores from th margins of Oregon [Lyle et al., 1992], California [Gardner al., 1997], and Mexico [Ganeshram, 1996], were much mo: gradual than the synchronized, rapid transition observed at th BA. Mix et al. [1999] observed a rapid increase in the organ carbon content of sediments at ODP site $1019\left(41.682^{\circ} \mathrm{I}\right.$ $124.903^{\circ} \mathrm{W}, 980 \mathrm{~m}$ water depth) at the onset of the BA, whic they interpreted as an increase in productivity. However, th corresponding changes in our California margin cores a more subdued, with an increase in percent $\mathrm{C}_{\text {org }}$ from $\sim 1.7 \%$ 
a)

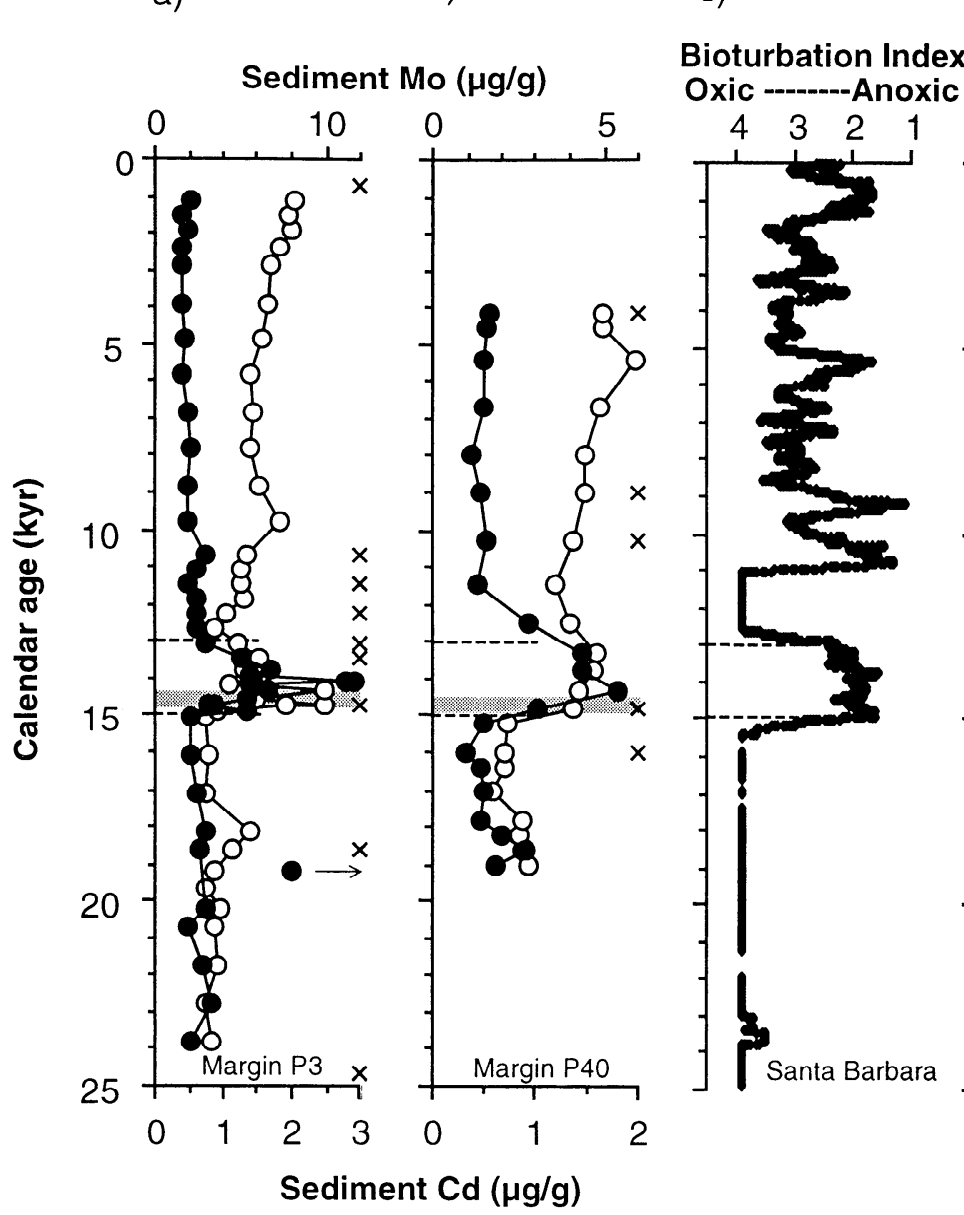

d)

e)

\section{$\delta{ }^{18} \mathrm{O}$ in Foraminifera Benthic-Planktonic}

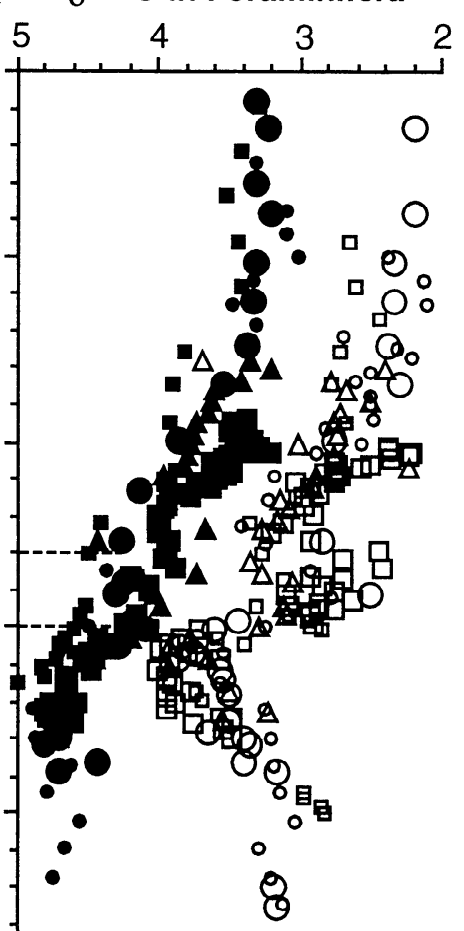

North Pacific

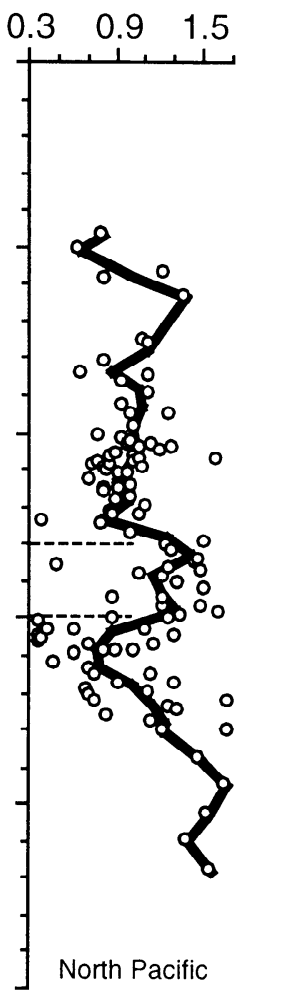

Figure 3. Variations in Mo (solid circle) and $\mathrm{Cd}$ (open circle) concentrations in sediments from the California margin at (a) $803 \mathrm{~m}$ (F2-92-P3) and (b) $760 \mathrm{~m}$ (F2-92-P40) at the depth of the present-day OMZ. Shaded intervals indicate periods of preservation of fine laminations. Crosses indicate calendar ages of accelerator mass sepctrometry ${ }^{14} \mathrm{C}$-dated foraminifera used to construct aged models for each core [Gardner et al., 1997] combined with new radiocarbon data for P40 (Table 1). Mo and Cd concentrations (Table 2) were measured by isotope-dilution inductively coupled plasma - mass spectrometry following a total acid dissolution of sediment [Zheng, 1999]. Detrital background concentrations, Mo of $\sim 2 \mu \mathrm{g} / \mathrm{g}$ and Cd of $\sim 0.1 \mu \mathrm{g} / \mathrm{g}$, do not vary significantly in either core [Taylor and McLennan, 1985]. Horizontal arrow corresponds to Mo determinations $(18$ and $29 \mu \mathrm{g} / \mathrm{g}$ at $312 \mathrm{~cm})$ that are not associated with any increase in Cd. (c) Smoothed bioturbation index record of Santa Barbara Basin ODP site 893 [Behl and Kennett, 1996], with larger values indicating higher degree of oxygenation. (d) Planktonic (open symbols) and benthic (solid symbols) foraminifera $\delta^{18} \mathrm{O}$ for sites in the far North Pacific (locations are indicated by solid circles in Figure 1): CH84-14 (large square), RAMA 44PC (small square), core 2594 (triangle), V34-90 (small circle), and PAR87A-10 (large circle) [Kallel et al., 1988; Zahn et al., 1991; Keigwin et al., 1992; Gorbarenko, 1996]. (e) Composite of difference in $\delta^{18} \mathrm{O}$ for all paired benthic and planktonic data. The thick line shows the difference between paired benthic and planktonic $\delta^{18} \mathrm{O}$ measured in the same cores averaged over 500 year intervals.

$15 \mathrm{kyr}$ to $\sim 2.2 \%$ by the end of the BA and with a further gradual increase to $2.7 \%$ through the Holocene [Gardner et al., 1997]. While the rise in percent $\mathrm{C}_{\text {org }}$ during the BA may have been influcnced by an increase in productivity, it may also have been a consequence of increased preservation under reduced concentrations of bottom water oxygen. The degree to which organic carbon preservation is regulated by bottom water oxygen has long been debated, but recent studies of $\mathrm{OMZ}$ sediments show conclusively that the quality and quantity of $\mathrm{C}_{\text {org }}$ preserved is sensitive to bottom water oxygen, especially at concentration $<20 \mu M$ [Keil et al., 1999; Paropkari and Keil, 1999]. Consequently, the increased $\mathrm{C}_{\text {org }}$ content of BA sediments cannot be used as conclusive evidence for increased productivity.

The authigenic $\mathrm{Cd}$ content of sediments is regulated both by bottom water oxygen concentration and by the rain of the particulate organic matter to the seafloor [van Geen et al., 1995]. The maximum Cd concentration in BA sediments is comparable to levels in late Holocene sediments (Figures 3a and $3 b$ ). Because bottom water oxygen concentrations during the BA were lower than today, as demonstrated by the preserved varves, the comparable $\mathrm{Cd}$ concentrations suggest that the rain of $\mathrm{C}_{\text {org }}$ during the BA may have been lower than today as well. It is difficult to estimate quantitatively changes 
Table 1. List of Raw AMS and Conventional ${ }^{14} \mathrm{C}$ Ages and Their Calendar Year Equivalent

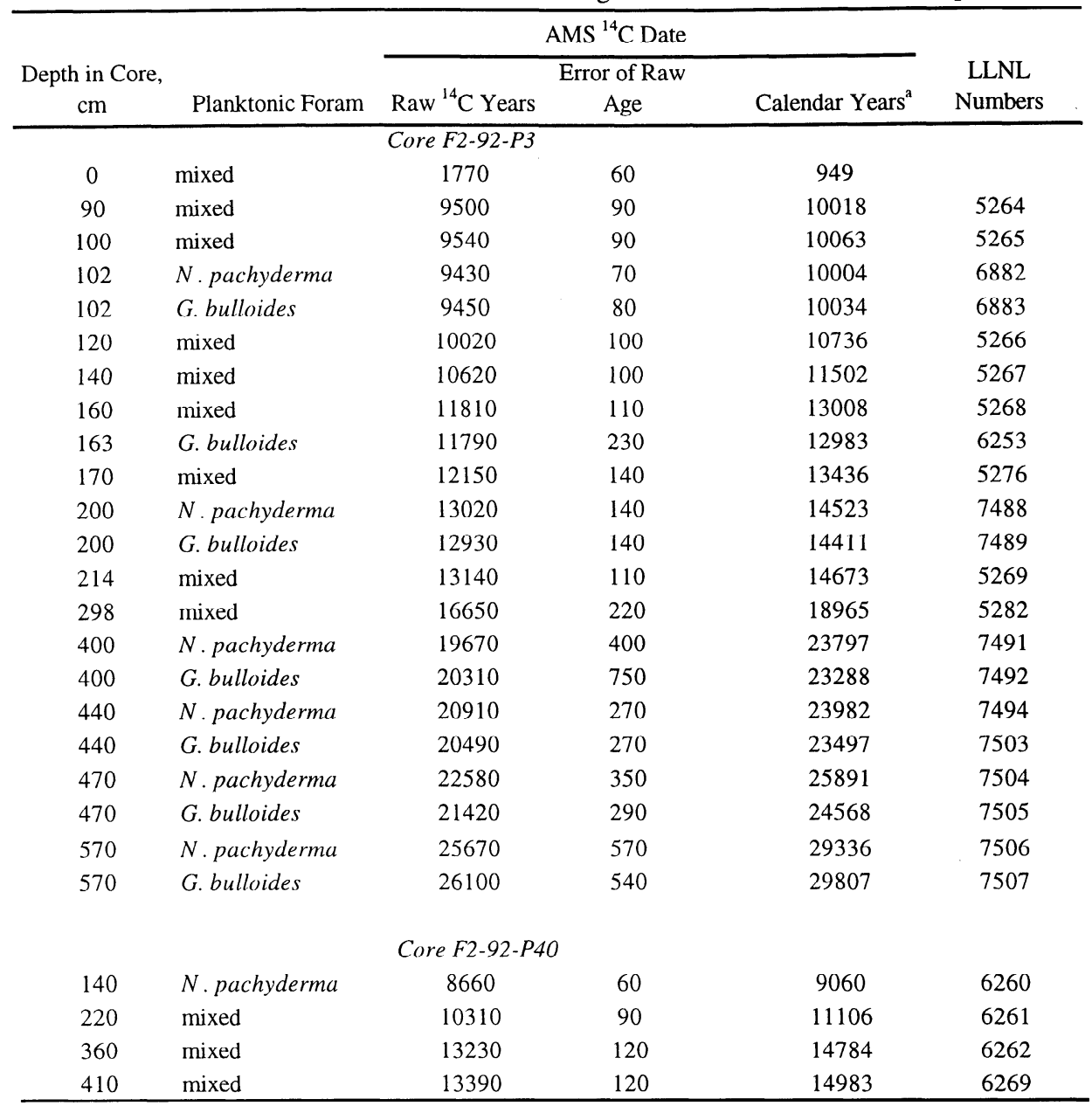

${ }^{\mathrm{a}}$ Calendar years is obtained by correcting a resevoir age of 625 years, followed by calculation

using equations (1) (<9 kyr) and (2) (>9 kyr) by Gardner et al . [1997].

in productivity from changes in sedimentary $\mathrm{Cd}$ and percent $\mathrm{C}_{\text {org }}$, but it is safe to conclude that productivity at the sites of our cores during the BA was no greater than today, and it may have been less. Therefore one must look to other factors to explain changes in $\mathrm{OMZ}$ intensity.

Records of the oxygen isotopic composition of planktonic and benthic foraminifera at five sites distributed across the far North Pacific, including the Gulf of Alaska and the Sea of Okhotsk, indicate changes in high-latitude surface forcing of ventilation during the BA (Figure 1a). The benthic records reflect primarily the release of ${ }^{18} \mathrm{O}$-depleted meltwater from continental ice sheets during deglaciation. The oxygen isotopic composition of planktonic foraminifera reflects a combination of factors, including the isotopic composition (which is rclated, in turn, to salinity) [Craig and Gordon, 1965; Zahn et al., 1991] and temperature [O'Neil et al., 1969] of the seawater in which calcification occurred. One feature that is common to all paired isotope records is that the difference between the oxygen isotopic composition of benthic and planktonic foraminifera $\left(\Delta \delta^{18} \mathrm{O}\right)$ nearly doubled from 0.7 to $1.3 \%$ o during the $\mathrm{BA}$, with almost all the changes associated with planktonic $\delta^{18} \mathrm{O}(\sim 1.4 \%$; Figures. $3 \mathrm{~d}$ and $3 \mathrm{e})$. If the modern salinity and $\delta^{18} \mathrm{O}$ relationship held at $15 \mathrm{kyr}$, then the
$0.6 \%$ increase in $\Delta \delta^{18} \mathrm{O}$ during the BA could be explained cither by $-1 \%$ reduction in surface salinity or by surface warming of $2.5^{\circ} \mathrm{C}$, or some combination thereof. The corresponding decrease in density is larger for a $1 \%$ salinity change $\left(\sim 0.8\right.$ unit) than for a $2.5^{\circ} \mathrm{C}$ temperature change $(0.2$ 0.4 units, depending on the initial temperature). The isotopic evidence for reduced surface water density during the BA is clear in all regions where NPIW forms today or coulc potentially have formed in the past. Because the intensity 0 the OMZ of the subtropical northeast Pacific is modulated by changes in ventilation at higher latitudes today, we conclud that the OMZ was particularly intense during the BA becaus of increased stratification at high latitudes.

What process enhanced the stratification of the high latitude North Pacific during the BA? A number o mechanisms, such as input of glacial meltwater and enhancer precipitation during the $\mathrm{BA}$, have been proposed to explain at apparent reduction in surface water salinity in the regio [Keigwin et al., 1992; Gorbarenko, 1996]. Warmer ani moister climate during the BA indicated by vegetation changes on Kodiak Island, Alaska, suggest that botl temperature and salinity may have played a role [Peteet an. Mann, 1994]. We believe, however, that tropical forcin: 
Table 2. Concentrations of $\mathrm{Cd}, \mathrm{Mo}, \mathrm{U}$, and Th in Piston Cores at $35^{\circ} \mathrm{N}$ California Margin

\begin{tabular}{|c|c|c|c|c|c|c|c|c|c|}
\hline Depth, cm & Calendar Age kyr ${ }^{a}$ & $\begin{array}{l}\text { Mo, } \\
\mu \mathrm{g} / \mathrm{g}\end{array}$ & $\sigma \mathrm{Mo}^{\mathrm{b}}$ & $\mathrm{Cd}, \mu \mathrm{g} / \mathrm{g}$ & $\sigma \mathrm{Cd}^{\mathrm{b}}$ & $\mathrm{U}, \mu \mathrm{g} / \mathrm{g}$ & $\sigma \mathrm{U}^{\mathrm{b}}$ & $\mathrm{Th}, \mu \mathrm{g} / \mathrm{g}$ & $\sigma \mathrm{Th}^{\mathrm{b}}$ \\
\hline & & $F 2-92-P 3$ & & $\left(35.6232^{\circ}\right.$ & $N, 121$. & $222^{\circ} \mathrm{W}$ & $786 m)$ & & \\
\hline TW5 & 0.78 & 1.64 & 0.24 & 1.88 & 0.01 & 4.78 & 0.05 & 10.11 & 0.05 \\
\hline TW 15 & 1.66 & 1.90 & 0.11 & 1.63 & 0.03 & 4.01 & 0.02 & 9.33 & 0.12 \\
\hline TW25 & 2.57 & 1.72 & 0.09 & 1.98 & 0.01 & 3.90 & 0.01 & 9.36 & 0.03 \\
\hline TW35 & 3.44 & 1.77 & 0.31 & 1.88 & 0.01 & 4.36 & 0.04 & 9.57 & 0.04 \\
\hline TW45 & 4.31 & 1.69 & 0.11 & 1.89 & 0.01 & 4.46 & 0.01 & 9.82 & 0.05 \\
\hline 4 & 1.10 & 2.01 & 0.10 & 2.03 & 0.00 & 5.18 & 0.03 & 9.97 & 0.10 \\
\hline 8 & 1.49 & 1.58 & 0.03 & 1.97 & 0.02 & 5.51 & 0.05 & 9.95 & 0.10 \\
\hline 12 & 1.89 & 1.91 & 0.08 & 2.02 & 0.04 & 4.96 & 0.00 & 10.20 & 0.06 \\
\hline 17 & 2.38 & 1.55 & 0.17 & 1.82 & 0.01 & 5.00 & 0.04 & 9.27 & 0.07 \\
\hline 22 & 2.88 & 1.57 & 0.17 & 1.71 & 0.01 & 4.89 & 0.01 & 10.72 & 0.07 \\
\hline 32 & 3.87 & 1.54 & 0.18 & 1.67 & 0.00 & 4.97 & 0.02 & 10.28 & 0.09 \\
\hline 42 & 4.85 & 1.75 & 0.02 & 1.56 & 0.00 & 4.82 & 0.00 & 10.17 & 0.01 \\
\hline 52 & 5.84 & 1.56 & 0.59 & 1.37 & 0.02 & 4.74 & 0.06 & 10.31 & 0.10 \\
\hline 62 & 6.83 & 1.94 & 0.29 & 1.45 & 0.02 & 4.62 & 0.03 & 9.80 & 0.07 \\
\hline 72 & 7.82 & 2.14 & 0.04 & 1.41 & 0.03 & 4.96 & 0.01 & 10.24 & 0.05 \\
\hline 82 & 8.81 & 1.91 & 0.08 & 1.52 & 0.01 & 4.91 & 0.06 & 10.26 & 0.02 \\
\hline 92 & 9.80 & 1.90 & 0.06 & 1.82 & 0.01 & 4.72 & 0.05 & 9.80 & 0.08 \\
\hline 102 & 10.67 & 2.87 & 0.25 & 1.35 & 0.00 & 4.85 & 0.04 & 10.19 & 0.12 \\
\hline 112 & 11.07 & 2.50 & 0.05 & 1.28 & 0.00 & 4.70 & 0.04 & 9.88 & 0.11 \\
\hline 122 & 11.47 & 1.90 & 0.21 & 1.24 & 0.02 & 4.67 & 0.03 & 10.00 & 0.09 \\
\hline 132 & 11.88 & 2.38 & 0.14 & 1.29 & 0.01 & 4.34 & 0.01 & 10.05 & 0.10 \\
\hline 142 & 12.28 & 2.36 & 0.11 & 1.05 & 0.02 & 4.49 & 0.05 & 9.93 & 0.10 \\
\hline 152 & 12.69 & 2.44 & 0.00 & 0.87 & 0.00 & 4.16 & 0.00 & 9.66 & 0.08 \\
\hline 162 & 13.09 & 2.89 & 0.12 & 1.20 & 0.01 & 5.04 & 0.05 & 10.54 & 0.10 \\
\hline 172 & 13.49 & 4.98 & 0.25 & 1.51 & 0.02 & 5.81 & 0.02 & 9.94 & 0.01 \\
\hline 182 & $i 3.77$ & 6.71 & 0.40 & 1.31 & 0.00 & 5.28 & 0.08 & 9.75 & 0.02 \\
\hline 187 & 13.91 & 5.48 & 0.37 & 1.52 & 0.00 & 5.51 & 0.01 & 10.25 & 0.01 \\
\hline 192 & 14.05 & 11.72 & 3.09 & 1.41 & 0.01 & 5.11 & 0.02 & 9.33 & 0.12 \\
\hline 192 & 14.05 & 11.10 & 1.08 & 1.43 & 0.01 & 5.25 & 0.04 & 8.97 & 0.08 \\
\hline 197 & 14.19 & 5.48 & 0.10 & 1.09 & 0.00 & 5.10 & 0.04 & 9.53 & 0.05 \\
\hline 202 & 14.36 & 6.60 & 0.97 & 2.47 & 0.01 & 5.93 & 0.10 & 8.66 & 0.13 \\
\hline 207 & 14.53 & 5.42 & 0.60 & 1.47 & 0.02 & 5.32 & 0.04 & 9.86 & 0.13 \\
\hline 212 & 14.70 & 3.51 & 0.21 & 1.93 & 0.03 & 5.49 & 0.03 & 9.86 & 0.06 \\
\hline 212 & 14.70 & 3.13 & 0.36 & 2.48 & 0.05 & 5.27 & 0.04 & 9.21 & 0.06 \\
\hline 217 & 14.88 & 5.33 & 0.54 & 0.93 & 0.01 & 4.28 & 0.02 & 8.75 & 0.14 \\
\hline 222 & 15.08 & 2.03 & 0.11 & 0.72 & 0.01 & 4.15 & 0.03 & 9.09 & 0.07 \\
\hline 242 & 16.10 & 2.08 & 0.40 & 0.78 & 0.00 & 4.66 & 0.04 & 9.17 & 0.13 \\
\hline 262 & 17.13 & 2.51 & 0.55 & 0.73 & 0.04 & 3.59 & 0.06 & 8.69 & 0.06 \\
\hline 282 & 18.15 & 2.99 & 0.26 & 1.39 & 0.01 & 5.31 & 0.01 & 9.67 & 0.06 \\
\hline 292 & 18.66 & 2.57 & 0.00 & 1.15 & 0.02 & 4.67 & 0.02 & 9.52 & 0.08 \\
\hline 302 & 19.17 & 7.95 & 0.04 & 0.87 & 0.02 & 4.89 & 0.03 & 7.82 & 0.05 \\
\hline 312 & 19.68 & 23.47 & 0.45 & 0.76 & 0.02 & 5.15 & 0.02 & 9.26 & 0.02 \\
\hline 322 & 20.19 & 2.90 & 0.06 & 0.94 & 0.02 & 4.48 & 0.04 & 7.96 & 0.18 \\
\hline 332 & 20.70 & 1.92 & 0.17 & 0.85 & 0.06 & 4.03 & 0.01 & 8.82 & 0.05 \\
\hline 352 & 21.72 & 2.72 & 0.16 & 0.93 & 0.03 & 4.62 & 0.01 & 9.19 & 0.01 \\
\hline 372 & 22.75 & 3.39 & 0.37 & 0.72 & 0.00 & 4.78 & 0.02 & 8.97 & 0.00 \\
\hline 392 & 23.77 & 2.15 & 0.38 & 0.84 & 0.00 & 3.88 & 0.01 & 8.82 & 0.06 \\
\hline
\end{tabular}

ultimately needs to be invoked in order to explain (1) the remarkable synchroneity between rapid climate change in the North Atlantic and the North Pacific regions over the course of deglaciation and (2) the antiphased pattern of changes in thermohaline circulation (THC) of the North Atlantic and
North Pacific Oceans, whereby ventilation of the North Atlantic shoaled during the LGM and YD as it deepened in the North Pacific and vice versa during the BA and Holocene [Kroon et al., 1997; Mikolajewicz et al., 1997; Lund and Mix, 1998; Marchitto et al., 1998]. 
Table 2. (continued)

\begin{tabular}{|c|c|c|c|c|c|c|c|c|c|}
\hline Depth, cm & Calendar Age kyr ${ }^{\mathrm{a}}$ & $\begin{array}{l}\text { Mo, } \\
\mu \mathrm{g} / \mathrm{g}\end{array}$ & $\sigma \mathrm{Mo}^{\mathrm{b}}$ & $\mathrm{Cd}, \mu \mathrm{g} / \mathrm{g}$ & $\sigma \mathrm{Cd}^{\mathrm{b}}$ & $\mathrm{U}, \mu \mathrm{g} / \mathrm{g}$ & $\sigma \mathrm{U}^{\mathrm{b}}$ & $\mathrm{Th}, \mu \mathrm{g} / \mathrm{g}$ & $\sigma \mathrm{Th}^{\mathrm{b}}$ \\
\hline & & \multicolumn{2}{|c|}{$F 2-92-P 40$} & \multicolumn{3}{|c|}{$\left(35.4182^{\circ} \mathrm{N}, 121.4158^{\circ} \mathrm{W}\right.$} & $760 \mathrm{~m})$ & & \\
\hline 1 & 4.14 & 1.64 & 0.20 & 1.66 & 0.01 & 4.18 & 0.05 & 7.70 & 0.10 \\
\hline 12.5 & 4.50 & 1.56 & 0.02 & 1.65 & 0.03 & 3.94 & 0.04 & 10.33 & 0.15 \\
\hline 42 & 5.44 & 1.44 & 0.20 & 1.96 & 0.03 & 4.30 & 0.02 & 9.34 & 0.05 \\
\hline 82 & 6.71 & 1.47 & 0.06 & 1.61 & 0.04 & 4.35 & 0.05 & 7.78 & 0.02 \\
\hline 122 & 7.99 & 1.13 & 0.08 & 1.48 & 0.02 & 3.81 & 0.02 & 8.31 & 0.04 \\
\hline 154 & 9.01 & 1.40 & 0.07 & 1.48 & 0.01 & 4.28 & 0.05 & 8.08 & 0.10 \\
\hline 194 & 10.28 & 1.59 & 0.10 & 1.37 & 0.00 & 3.90 & 0.01 & 7.75 & 0.07 \\
\hline 234 & 11.47 & 1.32 & 0.02 & 1.19 & 0.04 & 3.65 & 0.02 & 7.77 & 0.04 \\
\hline 274 & 12.52 & 2.77 & 0.00 & 1.32 & 0.00 & 4.52 & 0.02 & 8.15 & 0.02 \\
\hline 303 & 13.29 & 4.33 & 0.05 & 1.58 & 0.03 & 3.90 & 0.01 & 7.98 & 0.09 \\
\hline 323 & 13.81 & 4.38 & 0.46 & 1.57 & 0.07 & 4.19 & 0.02 & 8.11 & 0.00 \\
\hline 343 & 14.34 & 5.38 & 0.27 & 1.41 & 0.00 & 4.45 & 0.05 & 8.27 & 0.06 \\
\hline 363 & 14.84 & 3.04 & 0.25 & 1.36 & 0.01 & 4.20 & 0.01 & 7.86 & 0.00 \\
\hline 383 & 15.24 & 1.52 & 0.25 & 0.71 & 0.01 & 4.13 & 0.00 & 7.31 & 0.01 \\
\hline 423 & 16.03 & 1.00 & 0.09 & 0.69 & 0.01 & 4.31 & 0.03 & 6.83 & 0.04 \\
\hline 443 & 16.43 & 1.35 & 0.16 & 0.70 & 0.01 & 4.12 & 0.00 & 7.34 & 0.01 \\
\hline 473 & 17.02 & 1.44 & 0.03 & 0.57 & 0.01 & 3.69 & 0.00 & 7.60 & 0.04 \\
\hline 513 & 17.82 & 1.42 & 0.35 & 0.86 & 0.04 & 4.06 & 0.00 & 6.85 & 0.02 \\
\hline 533 & 18.21 & 1.98 & 0.02 & 0.83 & 0.06 & 3.85 & 0.01 & 8.02 & 0.09 \\
\hline 553 & 18.61 & 2.70 & 0.08 & 0.87 & 0.00 & 4.18 & 0.05 & 8.21 & 0.10 \\
\hline 573 & 19.01 & 1.83 & 0.03 & 0.91 & 0.01 & 3.67 & 0.02 & 8.29 & 0.05 \\
\hline
\end{tabular}

${ }^{a}$ Age model (Table 1) obtained following the method described by Gardner et al. [1997].

${ }^{\mathrm{b}}$ Here $\sigma$ indicates $1 \sigma$ analytical error of $\mathrm{Mo}, \mathrm{Cd}, \mathrm{U}$, and Th cocentrations.

Specifically, we propose that variations in the transport of water vapor from the tropical Atlantic Ocean to the Pacific Ocean controlled the inverse pattern of ventilation depth of the North Atlantic and the North Pacific Oceans since the LGM. The greater density of deep water formed at high latitude in the North Atlantic, compared to the Pacific, is maintained, in part, by excess evaporation in the North Atlantic and transport of water vapor across Central America to the Pacific by the trade winds [Broecker et al., 1990]. The rclation between water vapor transport and sea surface temperature (SST) is complex [Clement and Seager, 1999]. However, if we can assume that wind speed and relative humidity did not vary significantly in the tropical North Atlantic over the course of deglaciation, the change in evaporative flux from the region becomes primarily a function of SST. Coral records suggest that tropical Atlantic SST increased by several degrees during the transitions from LGM to BA and from YD to Holocene [Guilderson et al., 1994]. If tropical Atlantic SST increased from $20^{\circ}$ to $25^{\circ} \mathrm{C}$, for example, then this would translate into an increase of $\sim 40 \%$ in evaporation according to the ClausiusClapeyron equation and, presumably, into an increase in the transport of water vapor from the Atlantic to the Pacific. Increased water vapor transport across Central America would have reduced the salinity and therefore the density of surface waters advected to high latitudes of the North Pacific while increasing surface salinities in the North Atlantic. Because excess evaporation in the North Atlantic determines the overall nature and rate of deep water formation at high northern latitudes today [Weyl, 1968], it is plausible that changes in the flux of water vapor transported from the North
Atlantic to the North Pacific determined the inverse pattern of ventilation depth in the two basins during climatic fluctuations associated with the transition from the LGM to the Holocene.

Modern observations support the notion of antiphasec ventilation of the two ocean basins on relatively shor timescales. Repeated hydrographic transects across the Nortt Pacific Ocean have detected a distinct freshening of Nortl Pacific Intermediate Waters in recent decades, attributed tc increased precipitation (minus evaporation) at high latitudes [Wong et al., 1999]. Contemporary cruises in the Nortl Atlantic Ocean, on the other hand, have identified a stead: increase in salinity of the main thermocline and intermediats waters [Bryden et al., 1996]. It therefore appears that : mechanism similar to that invoked to explain changes ir ventilation of intermediate waters during climatic fluctuation: associated with the transition from the LGM to the Holocen may operate on shorter timescales as well.

Why was ventilation in the North Pacific more subduer during the BA than during the Holocene? Convection in th North Atlantic was also greater during the BA than at an: time since the LGM [Marchitto et al., 1998], leading som [Kroon et al., 1997] to characterize ocean thermohalin circulation at that time as operating in a "super conveyor mode. Varying the flux of water vapor across Central Americ provides a mechanism to explain not only the tempora component of antiphase behavior of high-latitude convectio: but also the intensity of convection. Early warming in th North Atlantic or some other as yet unidentified conditior may have generated a flux of water vapor across Centre America during the BA that has been unequaled anytime sinc 
then, creating both the super conveyor in the North Atlantic and restricting severely ventilation in the North Pacific.

Consequences for ocean thermohaline circulation and for global climate of varying the flux of water vapor across Central America have long been -appreciated; for example, Weyl [1968] suggested that a reduction of this flux could initiate an ice age by reducing the formation rate of North Atlantic Deep Water (NADW). While we are unaware of efforts to model the consequences of enhanced water vapor flux, as we propose for the BA, recent modeling of the converse effect, involving a net transfer of freshwater from the tropical Pacific to the tropical Atlantic, demonstrated the potential breakdown of NADW formation and the formation of a new convection cell in the North Pacific [Rahmstorf, 1995]. Our reconstruction further illustrates the important linkages between tropical SST, atmospheric water vapor transport, and ocean thermohaline circulation and provides a mechanism to explain the basin-scale antiphase behavior of ventilation in the North Atlantic and North Pacific Oceans.

Acknowledgments. We thank Mark Cane, Richard Seager, and Jean Lynch-Stieglitz for constructive discussion. Sediment core collection and selected analyses were supported by USGS. We also thank J. Kennett and M. Lyle for helpful reviews. Additional support was provided by NSF to AvG and RFA. This is Lamont-Doherty Contribution 6093

\section{References}

Alley, R.B., et al., Abrupt increase in Greenland snow accumulation at the end of the Younger Dryas event, Nature, 362, 527-529, 1993.

Behl, R.J., and J.P. Kennett, Brief interstadial events in the Santa Barbara Basin, NE Pacific, during the last $60 \mathrm{kyr}$, Nature, 379, 243-246, 1996.

Broecker, W.S., T.-H. Peng, J. Jouzel, and G. Russell, The magnitude of freshwater transports of importance to ocean circulation, Clim. Dyn., 4, 73-79, 1990.

Bryden, H.L., M.J. Griffiths, A.M. Lavin, R.C. Millard, G. Parilla, and W.M. Smethie, Decadal changes in water mass characteristics at $24 \mathrm{oN}$ in the subtropical North Atlantic Ocean, J. Clim., 9, 3162-3186, 1996.

Cannariato, K.G., and J.P. Kennett, Climatically related millennial-scale fluctuations in strength of California margin oxygen-minimum zone during the past 60 k.y., Geology, 27, 975-978, 1999.

Clement, A., and R. Seager, Climate and the tropical occan, J. Clim., 12, 3383-3401, 1999.

Cooperative Holocene Mapping Project (COHMAP) members. Climatic changes of the last 18,000 years: observations and model simulations, Science, 241, 1043-1052, 1988.

Craig, H., and L.I. Gordon, Deuterium and oxygen 18 variations in the ocean and the marine atmosphere, in Stable Isotopes in Oceanographic Studies and Paleotemperatures, Proceedings of the Third Spoleto Conference, edited by E. Tongiogi, pp. 9-130, V. Lischi and Figi, Pisa, Italy, 1965

Crusius, J., S. Calvert, T. Pedersen, and D. Sage, Rhenium and molybdenum enrichments in sediments as indicators of oxic, suboxic and sulfidic conditions of deposition, Earth Planet. Sci. Lett., 145, 65-78, 1996.

Dean, W.E., J.V. Gardner, and D.Z. Piper, Inorganic geochemical indicators of glacialinterglacial changes in productivity and anoxia on the California continental margin, Geochim. Cosmochim. Acta, 61, 4507-4518, 1997.

Emerson, S.R., and S.S. Huested, Ocean anoxia and the concentration of molybdenum and vanadium in seawater, Mar. Chem., 34, 177196, 1991.

Fairbanks, R.G., The age and origin of the "Younger Dryas climate event" in the Greenland ice core, Paleoceanography, 5, 937 948, 1990.

Francois, R., A study on the regulation of the concentrations of some trace metals $(\mathrm{Rb}, \mathrm{Sr}$, $\mathrm{Zn}, \mathrm{Pb}, \mathrm{Cu}, \mathrm{V}, \mathrm{Cr}, \mathrm{Ni}, \mathrm{Mn}$ and $\mathrm{Mo}$ ) in Saanich Inlet sediments, British Columbia, Mar. Geol., 83, 285-308, 1988.

Ganeshram, R., On the glacial-interglacial variability in upwelling, carbon burial and denitrification on the continental margin off northwestern Mexico, Ph.D. thesis, Univ. of British Columbia, Victoria, British Columbia, Canada, 1996.

Gardner, J.V., W.E. Dean, and P. Dartnell, Biogenic sedimentation beneath the California Current system for the past $30 \mathrm{kyr}$ and its paleoceanographic significance. Paleoceanography, 12, 207-225, 1997.

Gorbarenko, S.A., Stable isotope and lithologic evidence of late-glacial and Holocene oceanography of the Northwestern Pacific and its marginal seas, Quat. Res.N.Y., 46, 230-250, 1996.

Guilderson, T.P., R.G. Fairbanks, and J.L. Rubenstone, Tropical temperature variations since 20,000 years ago: Modulating interhemispheric climate change, Science, 263, 663-665, 1994

Helz, G.R., C.V. Miller, J.M. Charnock, J.F.W. Mosselmans, R.A.D. Pattrick, C.D. Gardner, and D.J. Vaughan, Mechanism of molybdenum removal from the sea and its concentration in black shales: EXAFS evidence, Geochim. Cosmochim. Acta, 60, 3631-3642, 1996.

Kallel, N., L.D. Labeyrie, M. Arnold, H. Okada, W.C. Dudley, and J.-D. Dupplessy, Evidence of cooling during the Younger Dryas in the western North Pacific, Oceanol. Acta, 11, 369. $375,1988$.

Keigwin, L.D., North Pacific deep water formation during the latest glaciation, Nature, 330, 362$364,1987$.

Keigwin, L.D., and G.A. Jones, Deglacial climatic oscillations in the Gulf of California, Paleoceanography, 5, 1009-1023, 1990.

Keigwin, L.D., G.A. Jones, and P.N. Froelich, A 15,000 year paleoenvironmental record from Meiji Seamount, far northwest Pacific, Earth Planet. Sci. Lett., 111, 425-440, 1992.

Keil, R., E. Tsamakis, and A. Devol, Amino acid composition and OC:SA rations indicate enhanced preservation of organic matter in Pacific Mexican margin sediments (abstract), Eos Trans AGU, 80(49), Ocean Sci. Meet. Supl., OS189, 1999.

Kennett, J.P., and B.L. Ingram, A 20,000 year record of ocean circulation and climate change from the Santa Barbara Basin, Nature, 377. $510-513,1995$

Kroon, D., W.E.N. Austin, M.R. Chapman, and G.M. Gassen, Deglacial surface circulation changes in the northeastern Atlantic: Temperature and salinity records off NW Scotland on a century scale, Paleoceanography, $12,755-763,1997$.

Levitus, S., and T. Boyer, World Ocean Atlas, Vol. 2: Oxygen, NOAA Atlas NESDIS 2, Natl. Oceanic and Atmos. Admin., Silver Spring, Md., 1994.

Lund, D.C., and A.C. Mix, Millennial-scale deep water oscillations: Reflections of the North Atlantic in the deep Pacific from 10 to $60 \mathrm{ka}$, Paleoceanography, 13, 10-19, 1998.

Lyle, M., R. Zahn, F. Prahl, J. Dymond, R. Collier, N. Pisias, and E. Suess, Paleoproductivity and carbon burial across the California Current: The multitracers transect, $42^{\circ} \mathrm{N}$, Paleoceanography, 7, 251-272, 1992.

Lynn, R.J., and J.J. Simpson, The California Current system: The seasonal variability of its physical characteristics, J. Geophys. Res., 92, 12947-12966, 1987.

Marchitto, T.M., W.B. Curry, and D.W. Oppo, Millennial-scale changes in North Atlantic circulation since the last glaciations, Nature. 393, 557-561, 1998.

Mikolajewicz, U., T.J. Crowley, A. Schiller, and R. Voss, Modeling teleconnections between the North Atlantic and North Pacific during the Younger Dryas, Nature, 387, 384-387, 1997.

Mix, A.C., D.C. Lund, N.G. Pisias, P. Borden, L. Bornmalm, M. Lyle, and J. Pike, Rapid climate oscillations in the northeast Pacific during the last deglaciation reflect Northern and Sourthern Hemisphere sources, in Mechanism of Global Climate Change at Millennial Time Scales, edited by P.U. Clark, R.S. Webb, and L.D. Keigwin, pp.127-148, Washington, D. C., 1999.

Nameroff, T.J., Suboxic trace metal geochemistry and paleo-record in continental margin sediments of the eastern tropical North Pacific, Ph.D. thesis, Univ. of Wash., Seattle, 1996.

Ohkouchi, N., H. Kawahata, M. Murayama, M. Okada, T. Nakamura, and A. Taira, Was deep water formed in the North Pacific during the Late Quaternary? Cadmium evidence from the northwest Pacific, Earth Planet. Sci. Lett., 124, 185-194, 1994

O'Neil, J.R., R.N. Clayton, and T.K. Mayeda, Oxygen isotope fractionation in divalent metal carbonates, J. Chem. Phys., 51, 5547-5558, 1969.

Paropkari, A., and R. Keil, OC:SA ratios in sediments of the Western Indian margin in the Arabian Sea: Evidence for the influence of bottom water oxygen over sedimentary organic matter content (abstract), Eos Trans. AGU, 80(49), Ocean Sci. Meet. Supl.. OS189. 1999.

Peteet, D.M., and D.H. Mann, Late-glacial vegetational, tephra, and climatic history of southwestern Kodiak Island, Alaska, Ecoscience, 1, 255-267, 1994.

Rahmstorf, S., Bifurcations of the Atlantic thermohaline circulation in response to changes in the hydrological cycle, Nature, 378, 145 $149,1995$.

Shaw, T.J., J.M. Gieskes, and R.J. Jahnke, Early diagenesis in differing depositional environments: The response of transition metals 
in pore water, Geochim. Cosmochim. Acta, 54, 1233-1246, 1990

Shimmield, G.B., and N.B. Price, The behavior of molybdenum and manganese during early sediment diagenesis -- Offshore Baja California, Mexico, Mar. Chem., 19, 261-280, 1986.

Talley, L.D., Distribution and formation of North Pacific Intermediate Water, J. Phys. Oceanogr., 23, 517-537, 1993.

Taylor, S.R., and S.M. Mclennan, The Continental Crust: Its Composition and Evolution, Blackwell Sci., Malden, Mass., 1985.

van Geen, A., D.C. McCorkle, and G.P. Klinkhammer, Sensitivity of the phosphatecadmium-carbon isotope relation in the ocean to cadmium removal by suboxic sediments, Paleoceanography, 10, 159-169, 1995.

Van Scoy, K.A., and E.R.M. Druffel, Ventilation and transport of thermohaline and intermediate waters in the Northeast Pacific during recent El Niños, J. Geophys. Res., 98, 18083-18088, 1993.

Weyl, P.K., The role of the oceans in climate change: A theory of the ice ages, Meteorol Monogr., 8, 37-62, 1968 .

Wong, A.P.S., N.L. Bindoff, and J.A. Church, Large-scale freshening of intermediate waters in the Pacific and Indian Oceans, Nature, 400 440-443, 1999.

Wyrtki, K., The oxygen minima in relation to ocean circulation, Deep Sea Res., 9, 11-23 1962.

Zahn, R., T.F. Pedersen, B.D. Bornhold, and A.C. Mix, Water mass conversion in the glacial subarctic Pacific $\left(54^{\circ} \mathrm{N}, 148^{\circ} \mathrm{W}\right)$ : Physical constraints and the benthic-planktonic stable isotope record, Paleoceanography, 6, 543-560, 1991.

Zheng, Y., The marine geochemistry of germanium, molybdenum and uranium: The Sinks, Ph.D. thesis, Columbia Univ., New York, 1999.
Zheng, Y., R.F. Anderson, A. van Geen, and J. Kuwabara, Authigenic molybdenum formation in marine sediments: A link to pore water sulfide in the Santa Barbara Basin, Geochim. Cosmochim Acta, in press, 2000

R.F.Anderson and A van Geen, I amontDoherty Earth Observatory, Columbia University, Palisades, NY 10964.

W. E. Dean, U. S. Geological Survey, MN 980 Federal Center, Denver, CO 80225.

J. V. Gardner, U. S. Geological Survey, 345 Middlefield Road, Menlo Park, CA 94025.

Y. Zheng, Queens College, City University of New York, Flushing, NY 11367. (yan_zheng (qc.edu)

(Received October 26, 1999;

revised April 4, 2000;

accepted May 18, 2000.) 